A

\title{
Research Article: Impact of National Food Security Mission with special reference to adoption level to field demonstration interventions in gram crop in southern Rajasthan
}

Article Chronicle Received : 29.03.2017;

Received :

12.04.2017;

Accepted :

26.04.2017

KeY Words : NFSM, Beneficiary, Interventions, Adoption, Demonstration

Author for correspondence :

\section{RAM LAL KHATIK}

Department of Extension Education, Rajasthan College of Agriculture, UDAIPUR (RAJASTHAN) INDIA Email : ramlalkhatik89 @ gmail.com

See end of the article for authors' affiliations

\author{
RAM LAL KHATIK, F.L. SHARMA, H.K. JAIN, SANTOSH DEVI SAMOTA \\ AND R.K. DAMOR
}

SUMMARY : The present study was conducted in Banswara and Udaipur districts of Southern Rajasthan. Total 120 gram beneficiary and non-beneficiary farmers were selected on the basis of random sampling method from the identified districts. The findings reveal that the extent of adoption of RSG888 variety of gram among beneficiary farmers was recorded 86.25 per cent, while in case of nonbeneficiary farmers it was 61.25 per cent. In case of extent of adoption of the complete package of practices of RSG-888 variety of gram, it was found that beneficiary and non-beneficiary farmers had 83.75 and 62.50 per cent adoption, respectively.

How to cite this article : Khatik, Ram Lal, Sharma, F.L., Jain, H.K., Samota, Santosh Devi and Damor, R.K. (2017). Impact of National Food Security Mission with special reference to adoption level to field demonstration interventions in gram crop in southern Rajasthan. Agric. Update, 12(2): 315-318; DOI : 10.15740/HAS/AU/12.2/ 315-318. 